\title{
Fotovoltaik Hücrenin Verimliliğinin Yapay Sinir Ağı İle Tahmini
}

\author{
Harun ÖZKİși *, Murat TOPALOĞLU ${ }^{1}$ \\ ${ }^{1}$ Bilgisayar Teknolojisi ve Bilişim Sistemleri Bölümü, Trakya Üniversitesi, Edirne, Türkiye \\ harunozkisi@trakya.edu.tr, murattopaloglu@trakya.edu.tr \\ (Geliş/Received:28.06.2016; Kabul/Accepted:29.06.2017) \\ DOI: $10.17671 /$ gazibtd.331035
}

\begin{abstract}
$\ddot{O}_{z} \boldsymbol{e t}$ - Teknolojinin hızla gelişmesi insan hayatındaki günlük elektronik eşya kullanımını arttırmıştır. Bu durum dünya üzerindeki enerji tüketiminde önemli bir artı̧sa sebep olmuştur. Enerji tüketiminin artması enerji sorununu ortaya çıkarmış ve bu sorunu aşmak için farklı enerji kaynaklarına yönelimler başlamıştır. Fosil yakıtların çevreye zarar vermesi ve tükenebilir olması alternatif enerji kaynaklarına yönelime yol açmıştır. Bu sorunu ortadan kaldırmak için güneş enerjisinin elektrik enerjisine çevirme fikri ortaya atılmıştır. Bu fikirden yola çıkılarak birçok uygulama hayata geçirilmiş ve bu uygulamalar hayatımızda yaygın bir hal almıştır. Fotovoltaik hücre ile yapılan bu uygulamaların gerilim elde etme açısından verimli olması oldukça önemli bir konu olarak karşımıza çıkmaktadır. Bu çalışmanın amacı, fotovoltaik hücrenin verimliliğini çevresel etkiler göz önünde bulundurarak Yapay Sinir Ağı teknolojisi ile tahmin etmektir. Bu tahmin için fotovoltaik hücrenim gerilim değerine karşılık rüzgâr hızı, sıcaklık, nem ve hücrenin açısı gibi çevresel faktörler dikkate alınmıştır. Veriler her bir faktör ve gerilim değerleri için ölçüm yapan bir düzenek ile belli bir zaman aralığı boyunca kayıt altına alınmıştır. Yapılan ölçümler sonucu elde edilmiş olan veriler ile panelin verimliliğini ortaya koyan bir Yapay Sinir Ağı modellenmiştir. Bu model fotovoltaik hücrenin verimlilik değerini yüzdelik olarak iyi bir şekilde tahmin etmektedir. Ayrıca ağın eğitim ve test işlemlerindeki performans ölçütlerinin oldukça iyi olduğu görülmektedir. Bu durum verimlilik tahmini için modellenmiş olan ağın tahmin yeteneğinin yüksek olduğunu göstermektedir.
\end{abstract}

Anahtar Kelimeler - Yapay Sinir Ağı, Fotovoltaik Hücre, Verimlilik, Çevresel Faktörler.

\section{The Estimation of the Photovoltaic Cell Productivity with the Use of Artificial Neural Network}

\begin{abstract}
The use of electronic devices has been greatly increased with the rapid developments in technology, which resulted in a huge increase in energy consumption in the world. As a result of increasing energy consumption, and because fossil fuels are both limited and harmful to the environment, a search for alternative energy resources has begun. The idea to convert Photovoltaic power into electricity was proposed as a solution, and several practices were implemented to serve that purpose. Most of these practices have already become common in daily life, and consequently, the productivity of the practices using Photovoltaic cells to create voltage has gained utmost importance. The aim of this study is to estimate the productivity level of Photovoltaic cells with the use of Artificial Neural Network technology in consideration with the environmental impacts. For this purpose, environmental factors, such as wind velocity, temperature, humidity and the angle of the cells were compared to the voltage rating of Photovoltaic cells to obtain data. The data were recorded at intervals with the use of a device measuring each factor and the voltage rating. According to the results of the measurements, an Artificial Neural Network was modelled that supports the productivity of the Photovoltaic panel. This model accurately estimates the productivity value of the photovoltaic cell as a percentage. It is also seen that the performance criteria of the network training and testing process are quite good. This indicates that the predictive ability of the network modeled for productivity estimation is high.
\end{abstract}

Keywords - Artificial neural network, Photovoltaic cells, Productivity, Environmental Factors. 


\section{GIRIȘ (INTRODUCTION)}

Güneş pilleri diğer bir adı ile fotovoltaik hücreler güneşten gelen 1 şı ğı gerilime çevirme prensibi ile çalışan ve fotovoltaik sistemlerin temelini oluşturun [1] aletler olarak karşımıza çıkmaktadır. Bu piller p-n tipi yarıiletken eklemlerinden oluşup yüzeyine düşen fotonların enerjilerinin bir k1smının, yariletkendeki serbest elektronları hareket ettirmesiyle elektrik akımı üretmektedir [2]. Çalışma şekli ve kullandığı kaynak açısından çevre dostu bir yapıya sahiptir. Tek başına çok yüksek düzeyde güç üretemeyen bu pillerden birbirlerine paralel veya seri bağlanarak kullanılabilir düzeyde güç elde etmek mümkündür. Paralel veya seri olarak bağlanarak bir yüzey üzerine monte edilmiş piller güneş pili modülünü oluştururlar. Fotovoltaik sistemler ise güneş pili modüllerinin uygulamaya bağlı olarak akümülatörler, invertörler (dönüştürücüler), akü şarj denetim aygıtları ve çeşitli elektronik destek devreleri ile birlikte kullanılarak oluşturulan yapılar olarak karşımıza çıkmaktadır[1]. Özellikle elektrik enerjisi üretiminde hesaba katılmayan ve görünmeyen maliyet olarak değerlendirilebilecek sosyal maliyet göz önüne alındığında; fotovoltaik sistemlerin fosile dayalı sistemlerden daha ekonomik olduğu söylenebilir [3]. Bu sebepten dolayı bu tür sistemler günümüzde enerji elde etmek için çok fazla tercih edilir duruma gelmiştir. Bu sistemlerin tercih ediliyor olması zamanla geliştirilmeye ihtiyaç duyulmasına neden olmaktadır. Bilim dünyasında bu alanda son bir yıl içerisinde yapılmış araştırmalara bakıldığında fotovoltaik uygulamalar için $\mathrm{ZnO}$ nanotel sentezinin yapıldığı [4], organik yariiletkenlerin katkılamasının verime olan etkisinin incelendiği [5], rüzgar ve biyogaz ile birlikte hibrit sistemlerinin dizayn edildiği [6] ve fotovoltaik sistemlerde kullanılan kablolardaki kayıpların incelendiği [7] çalışmalar göze çarpmaktadır. Bu çalışmaların genel anlamda sistemlerin daha verimli çalışmasını sağlamayı amaçladıkları görülmektedir. Bundan dolayı fotovoltaik sistemlerin verimli bir şekilde çalışmasının sağlanması önemli bir çalışma konusu olarak karşımıza çıkmaktadır. Bu çalışmada fotovoltaik hücrenin çevresel faktörlere bağlı olarak gerilim değeri üzerinden verimliliğinin tahminini yapan bir Yapay Sinir Ağı modelinin oluşturulması amaçlanmaktadır.

Yapay Sinir Ağları doğrusal olamayan problemlerin çözümünde etkili sonuçlar veren bir yapay zeka teknolojisi olup 1980 den beri bilim ve mühendislik alanlarında çalışan bilim adamlarının dikkatini çekmektedir [8]. Bu teknoloji ile doğrusal ilişkisi olamayan verilerin üzerinden sinıflama, tahmin etme, tanıma, yorumlama ve teşhis etme gibi işlemler yapılabilmektedir [9]. Bu özelliği sayesinde Yapay Sinir Ağları temelli birçok teknoloji geliştirilmiş ve bu alanda akademik olarak birçok çalışma yapılmıştır. Bu çalışmalar arasında fotovoltaik sistemlerle ilgili alanlar oldukça dikkat çekmektedir. Son y1larda yapay sinir ağ1 kullanılarak yapılmış bu alandaki tez çalışmaları incelendiğinde, $2.3 \mathrm{~kW}$ 'lık fotovoltaik bir sistemin ürettiği günlük enerji miktarının, bir yıllık meteorolojik veriler kullanılarak tahmini [10], fotovoltaik sistemlerde kısmî gölgelenme koşulları altında maksimum güç noktasının izlenebilirliği [11] ve maksimum güç noktası izleyicili ve uzay vektör modülasyonu eviricili fotovoltaik sistemin kontrolü [12] gibi çalışmalar görülmektedir. Bunun yanında son 10 yıl içerisinde yayınlanmış makaleler incelendiğinde tekli fotovoltaik güç sisteminin boyutlandırıldığ güneş radyasyon veri tahmini [13], fotovoltaik modülün elektriksel özelliklerinin tahmini için radyal taban fonksiyonu yaklaşımı [14], grid bağlantılı fotovoltaik bir tesiste performans tahmini için yapılmış uygulamas1 [15], bir gün öncesinden 24 saatlik fotovoltaik sistem için güç tahmini oluşturma [16], $20 \mathrm{~kW}_{\mathrm{p}}{ }^{\prime}$ lik şebekeye bağlı fotovoltaik tesisin performans tahmini [17], güç tahmininde komşu fotovoltaik sistemlerin etkisi için yapılan değerlendirme [18], konsantratör fotovoltaik teknolojisinin elektriksel karakterizasyonu için tekniklerin gözden geçirilmesi [19] ve Türkiye'deki tüm bölgeler için fotovoltaik modül verimliliğinin tahmini [20] gibi Yapay Sinir Ağları uygulamaları dikkati çekmektedir. Bu çalışmalarda genellikle giriş kriteri olarak sıcaklık ve güneş 1şığı kullanılmıştır. Aynı zamanda bu çalışmaların sistem içi performans arttırma amacını güttükleri görülmektedir. Ayrıca yapılan çalışmalarda ileri beslemeli Yapay Sinir A ğ yapısının tercih edildiği görülmüştür. Ayrıca son zamanlarda şebekeye bağlı akıllı hibrid fotovoltaik sistemin modellenmesi ve kontrolü[21] ve şebekeye bağlı akıllı hibrid pil / fotovoltaik sistemin modellenmesi, kontrolü ve simülasyonu [22] gibi yeni hibrid bulanık-sinirsel yöntemli sistemler üzerinde yapılmış çalışmalara rastlanmaktadır.

Bu çalışmada 4.2V-100mA'lik bir fotovoltaik hücre için rüzgâr hızı, sıcaklık, nem ve hücrenin yatayla yaptığı açısı gibi çevresel faktörlere bağlı olarak hücrenin verimi ile ilgili tahmin yapan bir Yapay Sinir Ağı modellenmiştir. Modelleme için gerekli olan veriler Edirne'nin Keşan ilçesinde belli bir zaman aralığında kayıt altına alınmıştır. Veriler dört adet giriş faktörü ve bu faktörler karşısında elde edilen gerilim değerleri için kayıt yapan bir düzenek sayesinde elde edilmiştir. Gerilim değerleri hücrenin üretebileceği maksimum değer dikkate alınarak yüzdelik verim değerlerine dönüştürülmüştür. Ve her bir kriter için eşleştirme yapılarak veri yapısı elde edilmiştir. Veriler eğitim ve test işlemlerinde kullanılmak üzere iki gruba ayırılmıştır. Eğitim verileri ağın mimarisinin belirlenmesi ve modellenmesi sırasında kullanılmıștır. Yapay Sinir Ağının test için ayırılmış veriler için tahmin ettiği yüzdelik verim değerleri ile sistemin ölçmüş olduğu gerçek yüzdelik verim değerleri arasında yüksek bir uyum olduğu görülmüştür.

\section{METERYAL VE METOT (MATERIAL AND METHOD)}

Bu araştırmada fotovoltaik hücre verimliliğiyle ilgili ileri beslemeli, çok katmanlı bir yapay sinir ağı uygulaması yapılmıştır. Uygulama teknik hesaplama, matematiksel problem çözümü ve analiz işlemleri için tasarlanmış olan MATLAB yazılım geliştirme aracı ile yapılmıştır. Bu araç özellikle mühendislik alanında geliştirilmiş sistemlerin 
analizi için çok fazla kullanılmakta ve iyi sonuçlar üretmektedir. Yapay Sinir Ağının performansı için Ortalama Karesel Hata (OKH), Ortalama Mutlak Hata $(\mathrm{OMH})$ ve determinasyon katsayısı $\left(\mathrm{R}^{2}\right)$ gibi kriterlerden yararlanılmıştır. Ağ için gerekli olan parametreler deneme yanılma yoluyla performans kriterleri dikkate alınarak belirlenmiştir. Analiz için kullanılan veriler her faktör için ayrı ayrı ölçüm yapabilen ve bu ölçümleri depolayabilen bir düzenek ile kayıt altına alınmıştır. Kayıt işlemi belli bir zaman dilimi içerisinde gerçekleştirilmiş ve bu kayıt sonunda ham veriler elde edilmiştir.

\subsection{Yapay Sinir A $\breve{g l a r l ~(A r t i f i c i a l ~ N e u r a l ~ N e t w o r k s) ~}$}

Yapay sinir ağı karmaşık yapılı doğrusal olmayan ilişkilere sahip problemlerin çözümünde kullanılan bir yapay zeka tekniği olarak bilinmektedir [23]. Bu teknik beyin çalışma ilkelerinin bilgisayar üzerinde uygulaması ile ortaya çıkmış, beyni oluşturan en küçük hücrelerin yani nöronların matematiksel olarak modellenmesi üzerinde yoğunlașmıștır[24]. Bu teknolojinin amacı beyindeki sinir hücresini taklit etmek ve bu yapıyı karmaşık problemlerin çözümü için bilgisayar sistemlerine uygulanmaktır[25]. Bu özelliğinden dolayı Yapay Sinir Ağları durum tahmin problemlerindeki potansiyel uygulamaların öncüsü olmuş ve son zamanlarda oldukça dikkat çekmiştir [26-29]. Çok katmanlı Yapay Sinir Ağları en basit anlamda girdi katmanı, gizli katmanlar ve çıtı katmanı olarak adlandırılan üç ana bölümden oluşmaktadır. $\mathrm{Bu}$ katmaların her birinde farklı sayıda nöron ya da işlem elemanı bulunmaktadır. Çalışmanın problemi dikkate alınarak yapılmış basit bir Yapay Sinir A $\breve{g} 1$ modeli Şekill'de verilmektedir. Bu model 4 işlem elemanlı giriş ve bir işlem elemanlı çıkış katmanından oluşmaktadır.

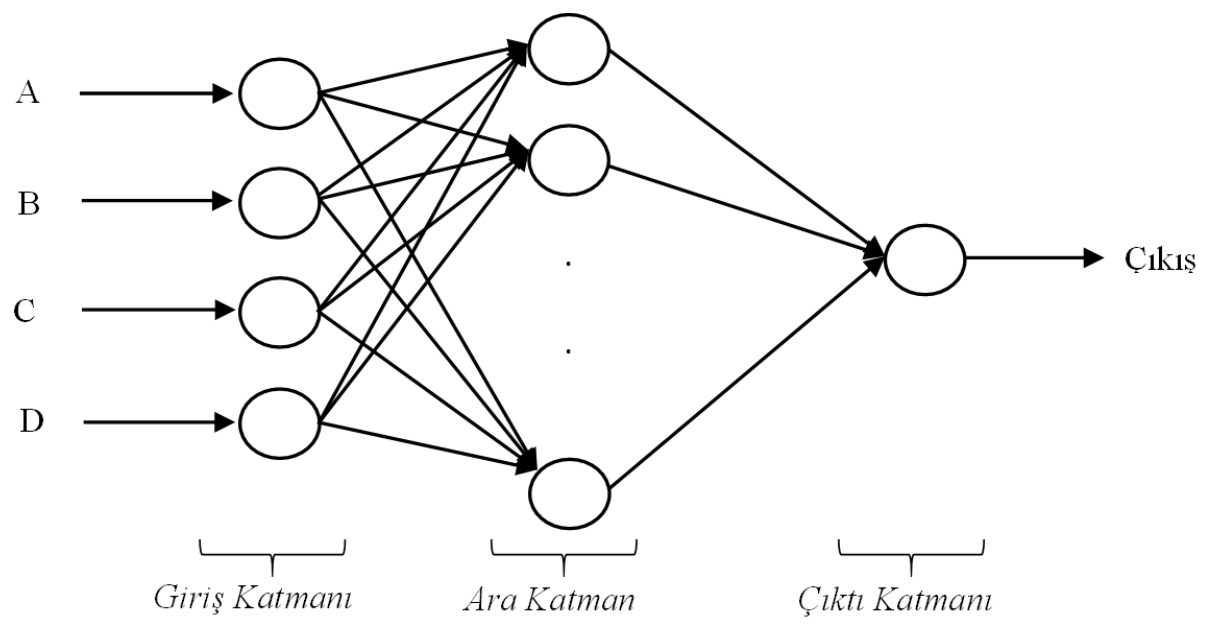

Șekil 1. Yapay Sinir Ağı modeli

(The artificial neural network model)

Ara katman sayısı bir tane olup işlem eleman sayısı belli değildir. $\mathrm{Bu}$ sayı problemin performansını etkilediğinden belli kriterler dikkate alınarak deneme yanılma yolu ile bir sonraki bölümde belirlenecektir. Giriș katmanındaki her bir işlem elemanına karşılık olarak belirlenmiş olan dört kriter
A. Havanın rüzgâr hızı
B. Hava sicaklığ 1
C. Havanın nem durumu
D. Fotovoltaik hücrenin zemin ile yaptığı açı

şeklinde maddeler halinde sıralanmaktadır. $\mathrm{Bu}$ kriterlerden havadaki rüzgar hızı, sıcaklık ve nem değerleri doğrudan ölçülmüştür. Fotovoltaik hücrenin zeminle yaptığı açı ise hücreyi belli zaman aralıklarında güneşi takip edecek şekilde hareket ettiren bir servo motor yardımı ile değiştirilmiştir. Yapılan her bir ölçümle birlikte buradaki açı değerleri de kayda alınmıştır. Buradaki amaç gün içerisinde hücrenin güneş 1şınlarını dik olarak almasını sağlamaktır. Çıkış prosesi olarak belirlenen kriteri ise Fotovoltaik hücrenin giriş parametreleri karşılığında gerçekleşen doğrudan ölçümü yapılmış gerilim değerleri temsil etmektedir. Yapay Sinir Ağı modellemesinde diğer bir önemli unsur ise ara katman sayısıdır. $\mathrm{Bu}$ sayı problemin özelliğine göre farklılık gösterebilir [30]. Bu çalışmada model oluşturmak için yapılan performans denemelerinde bir adet ara katmanın problemin çözümü acısından uygun olacağ kanısına varılmıştır.

\subsection{Performans Kriterleri (Performance Criteria)}

Bu çalışmadaki Yapay Sinir Ağının performansı için Ortalama Karesel Hata $(\mathrm{OKH})$, Ortalama Mutlak Hata $(\mathrm{OMH})$ ve determinasyon katsayısı $\left(\mathrm{R}^{2}\right)$ gibi üç farklı ölçütten yararlanılmıştır. Bu ölçütler istatistiksel parametrelerdir. $\mathrm{OKH}$, ölçüm değerleri ile model tahminleri arasındaki hata oranını belirlemek amaciyla kullanılmakta ve bu değerinin sıfıra yaklaşması modelin tahmin kabiliyetinin artması anlamına gelmektedir [31]. OMH, ölçüm değerleri ile model tahminleri arasındaki mutlak hatayı belirleme amacıyla kullanılmaktadır. OMH değeri sıfıra 
ne kadar yakın olursa modelinin tahmin yeteneği o kadar iyi demektir [32]. Determinasyon katsayısı $\left(\mathrm{R}^{2}\right)$, ölçüm değerleri ile model tahminleri arasında doğrusal bir ilişki olup olmadığını belirlemek amacıyla kullanılır. $\mathrm{R}^{2}$ değeri 0 ile 1 arasında değişmekte ve bu değerin 1'e yaklaşması model tahminleri ile ölçüm değerleri arasındaki bağımlılığın kuvvetli olduğu anlamına gelmektedir [33].

\subsection{Verilerin Elde Edilmesi (Extraction of Data)}

Güneș paneli verimliliğin ölçümünün yapılabilmesi için oluşturulan düzenekte arduino programlama dili yazılımlı microdenetleyici kart kullanılmıştır. $\mathrm{Bu}$ düzenek içerisinde kullanılan cihazların kalibrasyonları tölerans değerleri dikkate alınarak yapılmıștır. Donanımsal olarak kurulan düzenek içerisindeki malzemeler aşağıda listelenmiştir.

- $\quad 4.2 \mathrm{~V} 100 \mathrm{~mA}$ fotovoltaik hücre

- Pantilt Servo Sistemi

- Rüzgâr Hız Sensörü

- DS18B20 Sicaklık Sensörü

- DHT22 nem sensörü

$\mathrm{Bu}$ malzemeler ile oluşturulmuş bir düzenek sayesinde Fotovoltaik hücre için gerilim, Fotovoltaik hücrenin zeminle olan açı değeri, rüzgarın hızı, sıcaklık ve nem ölçümü yapılmıştır. Yapılan ölçümler Orijinal Arduino UNO R3 ve Sd Kart Modülü kullanılarak kayıt altına alınmıştır. Kayıt işlemini yapan düzeneğe ait akış diyagramı şekil 2'de verilmektedir.

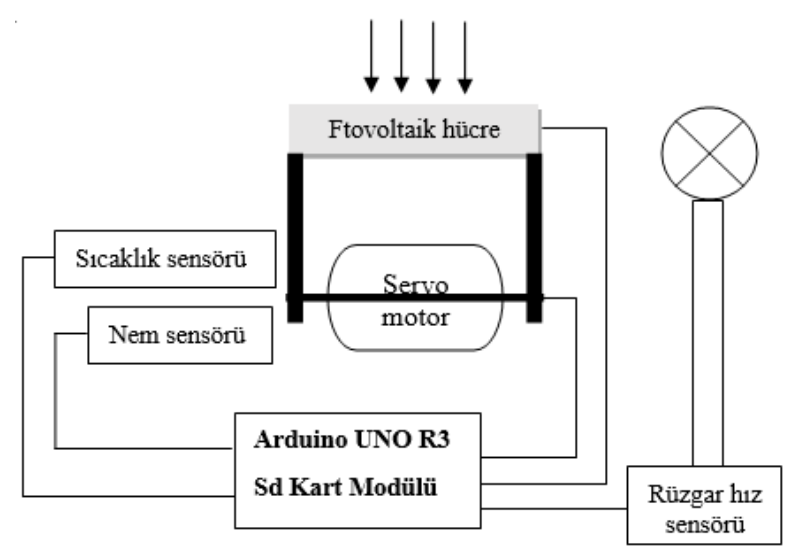

Şekil 2. Veri kayıt düzeneği akış diyagramı. (Data recording scheme flow diagram)

\section{BULGULAR (FINDINGS)}

\subsection{Veri Seti (Data Set)}

Çalışmanın verileri toplamda 5 farklı faktör göz önünde bulundurularak elde edilmiştir. $\mathrm{Bu}$ faktörler havanın sıcaklığı, nem oranı, rüzgar hızı ve fotovoltaik hücrenin açısı olarak isimlendirilen dört adet giriş parametresi ve bunlara karşılık elde edilmiş gerilim değerlerinin oluşturduğu bir adet çıkış parametresi olarak belirlenmiştir. Buradaki parametrelerin ölçümleri sıcaklık için $\left({ }^{0} \mathrm{C}\right)$, nem için $(\%)$, rüzgarın hızı için (km/saat), fotovoltaik hücrenin zemin ile olan açısı için (derece) ve fotovoltaik hücrenin gerilim değeri için ise (volt) birim değerlerinde yapılmıştır. Ölçümü yapılmış olan bu değerlere ait ortalama ve standart sapma değerleri Tablo1'de verilmiştir.

Tablo1. Veri kümesi ile ilgili istatistiki bilgiler (Statistical information about the dataset)

\begin{tabular}{llcc}
\hline \hline & & Ortalama & Standart Sapma \\
\hline \hline Sicaklık & $\left({ }^{0} \mathbf{C}\right)$ & 16,238 & 4,777 \\
Nem & $(\%)$ & 42,005 & 42,442 \\
Rüzgâr Hızı & $(\mathbf{k m} /$ saat $)$ & 2,625 & 2,364 \\
Açı & (Derece) & 54,536 & 48,969 \\
Gerilim & $($ Volt $)$ & 1,775 & 1,792 \\
\hline \hline
\end{tabular}

Veri seti içinden verimlilik değerlerinin belirlenmesi amaciyla gerilim değerleri için bir dönüşüm işlemi yapılmıştır. Dönüşüm işlemi volt değerleri üzerinden hücrenin ne kadar verimli çalıştığını ifade eden yüzdelik değerler elde edilerek yapılmıştır. Bu işlem için

Verim $=\frac{V}{V_{m a k}} \cdot 100$

formülü kullanılmıştır. Formüldeki $\mathrm{V}_{\text {mak }}$ hücrenin üretebildiği maksimum volt değeri, $\mathrm{V}$ herhangi bir kayıt için gerilim değeri ve verim ise volt değerleri üzerinden elde edilmiş olan yüzdelik verim değerini göstermektedir. Yüzdelik verim değerleri her bir kayıt için volt değerleri yerine yerleştirilmiştir. $\mathrm{Bu}$ dönüşüm sonucunda elde edilmiş olan veriler üzerinde normalizasyon işlemi yapılmıştır. Normalizasyon işlemi Yapay Sinir A $\breve{g ̆}_{1}$ modelinin hata oranını aza indirgemek amacıyla yapılmıştır. Bu işlem

$x_{i}=0.8 \frac{\left(x-x_{\min }\right)}{\left(x_{\operatorname{mak}}-x_{\min }\right)}+0.1$

formülü kullanılarak gerçekleştirilmiştir. Burada $x_{i}$ veri değeri $x$ ile gösterilen ham verinin normalize edilmiş halini göstermektedir. $x_{\operatorname{mak}}$ ve $x_{\min }$ ise veri setindeki maksimum ve minimum değerleri göstermektedir. Normalize edilmiş 194 verinin \%75'i ağın eğitimi için $\% 25$ 'i ise eğitilmiş olan ağın test edilmesi için kullanılmıştır. Eğitim ve test için kullanılacak olan verilerin seçimi homojen bir şekilde yapılmıştır. Ayrımı yapılmış veriler işlemler sırasında iki ayrı küme olarak ele alınmıştır.

\subsection{A $\breve{g}$ Mimarisi (Network Architecture)}

Doğru bir mimari yapı için ilk önemli olan unsur çözümü yapılacak olan problemin iyi bir şekilde tanımlanmış olmasıdır. Daha sonra bu tanımlamaya en uygun ağ mimarisinin belirlenmesi gerekmektedir. Oluşturulacak 
olan ağ modelinin başarılı olması için bu etkenler önemli bir yer tutmaktadır. Mimari yapının belirlenmesindeki en önemli etkenler ise probleme uygun öğrenme algoritması ve ağın gizli katmandaki işlem elemanı sayısının belirlenmesi olarak sıralanabilir. Buradaki amaç en uygun algoritmayı kullanarak girdi ve çıktı verileri arasındaki bağlantıyı sağlayan ağırlık değerlerini elde etmektir. Bu amaç doğrultusunda probleme uygun olarak belirlenmiş olan algoritmalar yoluyla oluşturulan ağ modelleri karşılaştırılmıştır. Karşılaştırma kriterleri olarak Ortalama Karesel Hata $(\mathrm{OKH})$ ve determinasyon $\left(\mathrm{R}^{2}\right)$ değerleri dikkate alınmıştır. Yapay Sinir Ağı modellinin oluşturması sırasında farklı algoritmalar için yapılan eğitim hesaplamaları sonucunda elde edilmiş olan $\mathrm{OKH}$ ve $\mathrm{R}^{2}$ değerleri belirlenmiştir. Bu değerler arasında en küçük OKH değeri 0,00009140 ve en büyük $\mathrm{R}^{2}$ değeri 0,99936'ya sahip olan Levenberg-Marquardt algoritmas1 problem için en uygun algoritma olarak belirlenmiştir. Ayrıca gizli katmandaki işlem elemanı sayısının belirlenmesi amacıyla katmandaki farklı işlem eleman sayısı değerleri için OKH değerleri hesaplanmıştır. İşlem elemanı sayısının $\mathrm{OKH}$ değerlerine göre değişimi şekil 3 'te verilmektedir.

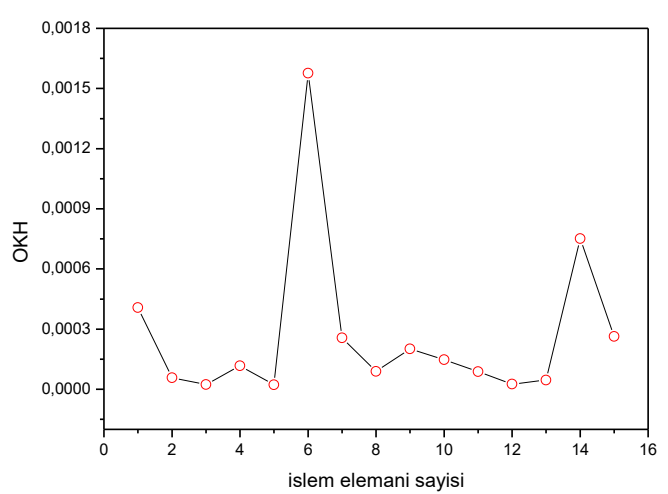

Şekil 3. İşlem eleman sayısının Ortalama Karesel Hataya göre değişimi

(Mean Square Error change according to the number of processing elements)

Şekilden görüldüğü gibi 3,5 ve 12 işlem eleman sayısı değerlerinde lokal minimum OKH değerleri elde edilmiştir. Fakat bunlar arasında 0,00002281 ile en küçük hata değerine sahip 5 işlem elemanlı mimari yapının en iyi performansa sahip olduğu görülmektedir.

\subsection{Eğitim ve Test (training and test)}

Yapılan hesaplamalar sonucunda fotovoltaik hücrenin gerilim cinsinden verimliliğini en iyi tahmin eden ağ mimarisi (4-5-1) olarak belirlenmiştir. $\mathrm{Bu}$ mimariye yönelik yapılmış olan test ve eğitim işlemlerinin performans değerleri tablo 2'de verilmiştir.
Tablo 2. Yapay sinir ağının eğitim ve test performansları (the training and test performance of the neural network)

\begin{tabular}{lll}
\hline \hline & Ĕ̆itim & Test \\
\hline \hline OKH & 0.000148 & 0.000042 \\
OMH & 0.005748 & 0.003994 \\
$\mathbf{R}^{2}$ & 0.999480 & 0.999720 \\
\hline \hline
\end{tabular}

Tabloda eğitim ve test işlemlerinin her ikisi için de elde edilmiş performans kriter değerlerinin iyi düzeyde çıktığ 1 görülmektedir. Burada elde edilen $\mathrm{OKH}$ ve $\mathrm{OMH}$ değerlerinin sıfıra $R^{2}$ değerlerinin ise bire yakın olması elde edilmiş ağ mimarisinin tahmin yeteneğinin gerçeğe yakın olması anlamına gelmektedir. Şekil 4'te test verileri için gerçek verim değerleri ile Yapay Sinir Ağlarının tahminine göre elde edilen verim değerlerinin karşılaştırılması verilmiştir.

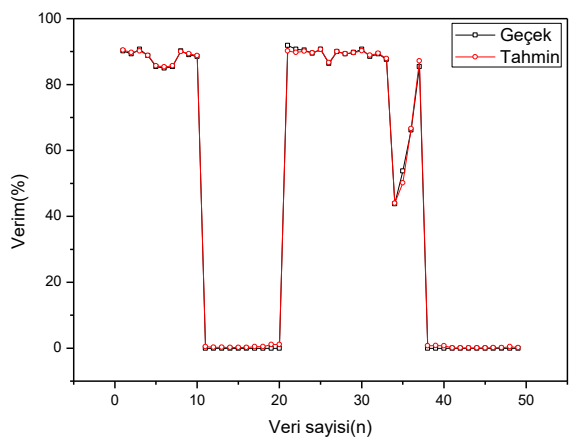

Şekil 4. Test verilerinin gerçek ve tahmini değerleri (actual and estimated value of the test data)

Şekilde ölçüm değerleri ile Yapay Sinir Ağlarının tahmin ettiği değerler arasında oldukça iyi bir uyum olduğu gözükmektedir. Test verileri veri seti içerisinden homojen olarak seçilmiştir. Bu şekilde yapılan seçim ile Yapay Sinir Ağının problem uzayını daha iyi temsil etmesi sağlanmıştır. Bu yüzden çapraz doğrulama yapılmasına gerek duyulmamıştır. Aynı zamanda bu durum eğitim sırasında da ağın performansını da olumlu etkilemiştir.

\section{SONUÇ VE ÖNERİLER (CONCLUSION AND SUGGESTIONS)}

Sonuç olarak bu çalışmada fotovoltaik hücreler için belirlenmiş olan rüzgâr hızı, sıcaklık, nem ve açı faktörlerine göre verimlilik tahmini yapan (4-5-1) mimari yapısına sahip bir yapay sinir ağı modellenmiştir. Modellenmiş olan yapay sinir ağı Fotovoltaik hücrenin verimliliğini çok iyi bir şekilde tahmin edebilmektedir. Elde edilen modelin, eğitim ve test işlemlerinde düşük hata ve oldukça yüksek seviyede determinasyon değerlerine sahip olduğu görülmüştür. $\mathrm{Bu}$ durum ağın tahmin ile gerçek değerler arasında çok az hata yaptığ aynı zamanda tahmin değerlerinin gerçek değerlerle kuvvetli bir ilişkisi olduğu sonucunu ortaya çıkarmaktadır. $\mathrm{Bu}$ çalışma sonucunda, MATLAB programı yardımıyla fotovoltaik hücrelerin verimli bir şekilde kullanılabilmesine olanak sağlayan bir Yapay 
Sinir Ağ1 modeli oluşturulmuştur. Bu model Fotovoltaik hücrenin gerilim değerleri üzerinden bir verim tahmini yapmaktadır. Elde edilen ağırlık değerleri dikkate alınarak $\mathrm{C}$ tabanlı herhangi bir program ile bu model uygulamaya geçirilebilir. Bu uygulama bir fotovoltaik sisteme entegre edilerek sistemin daha verimli bir şekilde çalışması sağlanmış olacaktır. Sonuç olarak enerji elde etme açısından son derece önemli bir konuma ulaşmıș olan ve önemi gün geçtikçe artan fotovoltaik sistemlerde Yapay Sinir Ağlarının kullanılmasının daha verimli şekilde enerji elde etmeye yol açacağı düşünülmektedir. Buna karşı olarak sistemin olușturulması için kullanılan veri belli bir zaman aralığında elde edilmiştir. Zaman aralığ arttırılarak daha fazla veri ile sistemin geliştirilmesi sağlanabilir. Ayrıca tahmin için kullanılan kriterler arttırılarak daha hassas bir tahmin yapılabilir.

\section{KAYNAKLAR (REFERENCES)}

[1] A. Ö. Küpeli, Güneş Pilleri Ve Verimleri, Yüksek Lisans Tezi, Osmangazi Üniversitesi, Fen Bilimleri Enstitüsü, 2005.

[2] A. Batman, Elektrik Üretimi İçin Güneş Pillerinin Kullanımında Verimi Arttırıcı Yeni Bir Yöntem, Doktora Tezi, İstanbul Teknik Üniversitesi, Fen Bilimleri Enstitüsü, 2001.

[3] Ş. Oktik, 2001, Güneş Elektrik Dönüşümleri Fotovoltaik Güneş Gözeleri ve Güç Sistemleri, Ankara Temiz enerji Vakfi Yayınları, 40s.

[4] M. Deveci, Fotovoltaik Uygulamalar İcin Zno Nanotel Sentezi Ve Elektrooptik Özelliklerin İncelenmesi, Yüksek Lisans Tezi, Hacettepe Üniversitesi, Fen Bilimleri Enstitüsü, 2016.

[5] M. K. Hergün, Organik Yariiletkenlerin Katkılanması Ve Fotovoltaik Uygulamaları, Yüksek Lisans Tezi, Ege Üniversitesi, Fen Bilimleri Enstitüsü, 2016.

[6] M. Habıbullah, Rüzgar-Fotovoltaik- Biyogaz Hibrit Güc Sistemlerinin Akıllı Mikro Şebekelerde Kullanımının Kontrol Ve Dizaynı, Yüksek Lisans Tezi, Ege Üniversitesi, Fen Bilimleri Enstitüsü, 2016

[7] M. A. Köprü, Fotovoltaik Sistemlerde Kablo Kayıplarının İncelenmesi, Yüksek Lisans Tezi, Fırat Üniversitesi, Fen Bilimleri Enstitüsü, 2016.

[8] Y. Luoa, Z. Wangb, G. Weia, F. E. Alsaadic, T. Hayatc, "State estimation for a class of artificial neural networks with stochastically corrupted measurements under Round-Robin protocol", Neural Networks, Vol 77, P 70-79, 2016.

[9] E. Öztemel, Yapay Sinir Ağları, Popatya Yayıncılık, 3, İstanbul, 2012.

[10] K. Donuk, Şebekeye Bağlı Fotovoltaik Sistemlerde Üretilen Enerjinin Yapay Sinir Ağları Kullanılarak Tahmini, Yüksek Lisans Tezi, Fırat Üniversitesi, Fen Bilimleri Enstitüsü, 2014.

[11] S. D. Erdoğan, Fotovoltaik Sistemlerde Yapay Sinir Ağları İle Maksimum Güç Noktası İzleyicisi Tasarımı, Yüksek Lisans Tezi, Ege Üniversitesi, Fen Bilimleri Enstitüsü, 2011.

[12] A. A. Kulaksız, Maksimum Güç Noktası İzleyicili Ve UVM İnverterli Fotovoltaik Sistemin Yapay Sinir Ağları Tabanl Kontrolü, Doktora Tezi, Selçuk Üniversitesi, Fen Bilimleri Enstitüsü, 2007.
[13] A. Mellit, M., Menghanem, M. Bendekhis, "Artificial neural network model for prediction solar radiation data: application for sizing stand-alone photovoltaic power system", In Power Engineering Society General Meeting, IEEE, pp. 40-44, 2005

[14] F., Bonanno, G., Capizzi, G., Graditi, C., Napoli, G. M., Tina, "A radial basis function neural network based approach for the electrical characteristics estimation of a photovoltaic module" Applied Energy, 97 , 956-961, 2012.

[15] A., Mellit, A. M. Pavan, "A 24-h forecast of solar irradiance using artificial neural network: Application for performance prediction of a grid-connected PV plant at Trieste, Italy.” Solar Energy, 84(5), 807-821, 2010

[16] A., Yona, T., Senjyu, A. Y., Saber, T., Funabashi, H., Sekine, C. H., Kim, "Application of neural network to one-day-ahead 24 hours generating power forecasting for photovoltaic system." In Intelligent Systems Applications to Power Systems, 2007. ISAP 2007. International Conference on (pp. 1-6). IEEE, 2007.

[17] A., Mellit, A. M., Pavan, "Performance prediction of 20kW p gridconnected photovoltaic plant at Trieste (Italy) using artificial neural network." Energy Conversion and Management, 51(12), 2431-2441, 2010.

[18] A. G. R., Vaz, B., Elsinga, W. G. J. H. M., van Sark, M. C., Brito, "An artificial neural network to assess the impact of neighbouring photovoltaic systems in power forecasting in Utrecht, the Netherlands." Renewable Energy, 85, 631-641, 2016.

[19] F., Almonacid, E. F., Fernandez, A., Mellit, S., Kalogirou, "Review of techniques based on artificial neural networks for the electrical characterization of concentrator photovoltaic technology." Renewable and Sustainable Energy Reviews, 75, 938-953, 2017.

[20] İ., Ceylan, E., Gedik, O., Erkaymaz, A. E., Gürel, "The artificial neural network model to estimate the photovoltaic modul efficiency for all regions of the Turkey." Energy and Buildings, 84, 258-267, 2014

[21] A., Rezvani, M., Gandomkar, "Modeling and control of grid connected intelligent hybrid photovoltaic system using new hybrid fuzzy-neural method." Solar Energy, 127, 1-18, 2016.

[22] A., Rezvani, A., Khalili, A., Mazareie, M., Gandomkar, "Modeling, control, and simulation of grid connected intelligent hybrid battery/photovoltaic system using new hybrid fuzzy-neural method." ISA transactions, 63, 448-460, 2016.

[23] T. Cakar, A. K. Türker ve A. Toraman. "İmalat sistemlerinin tasarlanmasında Yapay Sinirsel Ağların Kullanılması” Birinci Ulusal Zeki İmalat Sistemleri Sempozyumu Zís'96'da Sunulan Bildiri, Sapanca-Sakarya, 30-31, Mayis, 1996.

[24] Ö. Efe, O. Kaynak, Yapay Sinir Ağları ve Uygulamaları, Boğaziçi Üniversitesi Yayınları, Basım No:696, İstanbul, 2002.

[25] B. Eren, ve S.M. Turp, "Sizıntı Suyundan Nikel (I1) İyonlar Giderim Veriminin Yapay Sggngr Ağları ile Tahmin Edilmesi”, Journal of New World Sciences Academy Engineering Sciences, 1A0161, 6, (1), 398-405 2011.

[26] K. Mathiyalagan, H. Su, P. Shi, R. Sakthivel, "Exponential Ho Filtering For Discrete-Time Switched Neural Networks With Random Delays”, IEEE Transactions on Cybernetics, 45(4), 676-687, 2015.

[27] P. Shi, Y. Zhang, R. K. Agarwal, "Stochastic finite-time state estimation for discrete time-delay neural networks with Markovian jumps", Neurocomputing, 151, 168-174, 2015. 
[28] Z. Wang, D. W. Ho, X. Liu, "State estimation for delayed neural networks", IEEE Transactions on Neural Networks, 16(1), 279-284, 2005 .

[29] Z. Wang, Y. Liu, X. Liu, "State estimation for jumping recurrent neural networks with discrete and distributed delays", Neural Networks, 22(1), 41-48, 2009.

[30] T. Aydoğan, S. Çömlekçi ve M. Albayrak, "Yapay Sinir Ağlarında Öğrenme Yeteneği Uygulaması", Süleyman Demirel Üniversitesi Fen Bilimleri Enstitüsü Dergisi, 4(1), 5-10, 2000.
[31] K.P. Singh, A. Basant, A. Malik, G. Jain, "Artificial Neural Network Modeling Of The River Water Quality-A Case Study", Ecological Modelling, Volume:220, Number:6, 888-895, 2009.

[32] N.S. Kaveh, S.N. Ashrafizadeh, F. Mohammadi, "Development of an artificial neural network model for prediction of cell voltage and current efficiency in a chlor-alkali membrane cell" Chemical Engineering Research and Design, Volume:86, Number:5, 461-472, 2008.

[33] E. Doğan, A. Ateş, E.C. Yılmaz, B. Eren, “Application of Artificial Neural Networks to Estimate Wastewater Treatment Plant Inlet Biochemical Oxygen Demand" Environmental Progress, Volume:27, Number:4 , 439-446, 2008. 